\title{
Issue Activity of Subjects of the Russian Federation and Municipalities: Tendencies of the Beginning of the XXI Century
}

\author{
Sharafutdinova I.R. \\ Kazan Federal University, Institute of Management, Economics and Finance, Kazan, 420008, Russia \\ Email: kafedra_finansov@mail.ru \\ Kulakova S. A. \\ Kazan Federal University, Institute of Management, Economics and Finance, Kazan, 420008, Russia
}

Nikonova E. N.

Kazan Federal University, Institute of Management, Economics and Finance, Kazan, 420008, Russia

Email: kafedra_finansov@mail.ru

\section{Doi:10.5901/mjss.2014.v5n24p204}

\section{Abstract}

The article is devoted to research of practice of issue of the state securities of the subjects of the Russian Federation and securities of municipalities during the period from 2000 to 2014. The work purpose - research of dynamics of issue activity of subjects of the Russian Federation and municipalities, definition of the tendencies which have developed for the analyzed period in issue activity. The group of territorial subjects of the Russian Federation - issuers of the state bonds on the degree of investment activity was carried out, the directions of use of means from issue of bonds are allocated. Besides, suggestions for improvement of practice of the issue activity of regional and municipal authorities are made.

Keywords: subfederal bonds, municipal bonds, regional economy, debt, budget, Russian Federation, region.

\section{Introduction}

Among the main actions in a state program of the Russian Federation "Management of public finances and regulation of the financial markets" monitoring of a condition of a public debt of the subjects of the Russian Federation and a municipal debt, and also providing the admission is allocated for the market of financial and steady issuers of securities" [5].

Being a source of a covering of a budget deficit, subfederal loans bear in themselves the budgetary risks. The policy of unreasonable building of a debt can worsen debt stability of the budget and lead to decrease in quality of management by public finance. Increase of reliability of subfederal borrowers and their budgets in the national financial market is an actual problem of a modern state policy [5]. In this regard the analysis of practice of issues of the bonds, which are carried out by regional and municipal authorities of Russia, will allow not only to allocate the main tendencies and parameters of already carried out loans, but also to estimate the prospects of development of this sphere. Information base of research includes the data published on the official sites of the federal ministries and statistical bodies.

\section{Theory}

The main document regulating the sphere of the state and municipal loans, the Budgetary code of the Russian Federation, which has been put into operation since January 1, 2000 is. The methodology on research of processes of issue of the state securities of regions and securities of municipalities was formulated in works of foreign and domestic scientists. Among the authors who made a powerful contribution to the solution of methodological problems in this sphere, M. Aguiar, M. Amador [1], A. N. Dankov [2], E. Dobson [3], F. D. Fabozzi [4], X. Feng [5] and others. 


\section{Results}

According to the Ministry of Finance of the Russian Federation, on January 1, 2014 the public debt of territorial subjects of the Russian Federation made 1,74 trillion rub, having increased in a year almost by $30 \%$ (with 1,35 trillion rub), the volume of a debt of municipalities grew by $18 \%$ (from 245 billion rubles in 288,9 billion rubles) [9].

In 2013 the structure of a public debt of territorial subjects of the Russian Federation changed: the share of obligations for the budgetary credits decreased, and the specific weight of the credits from commercial banks increased [10]. The main debt of municipalities is issued bank (more than $50 \%$ of a total debt) and the budgetary credits (about $32 \%$ ), only $4 \%$ were the share of municipal bonds. The relation of a public debt of territorial subjects of the Russian Federation to the income (without gratuitous receipts) following the results of 2013 made $33 \%$, and the relation of the sum of payments for repayment and service of a debt of territorial subjects of the Russian Federation to the income of regional budgets (without gratuitous receipts) - 13\% [10].

For January 1, 2014 debt papers of 36 territorial subjects of the Russian Federation and 5 municipalities are traded on the market of regional bonds. Their share of the total amount of the market of ruble bonds - 5,3\% (5,6\% - in 2013) that is connected with a rather small number of issuers - territorial subjects of the Russian Federation which use the tools of a public debt for financing.

In figure 1 dynamics of issues of the state securities of territorial subjects of the Russian Federation and municipal securities during 2000-2014 is shown.

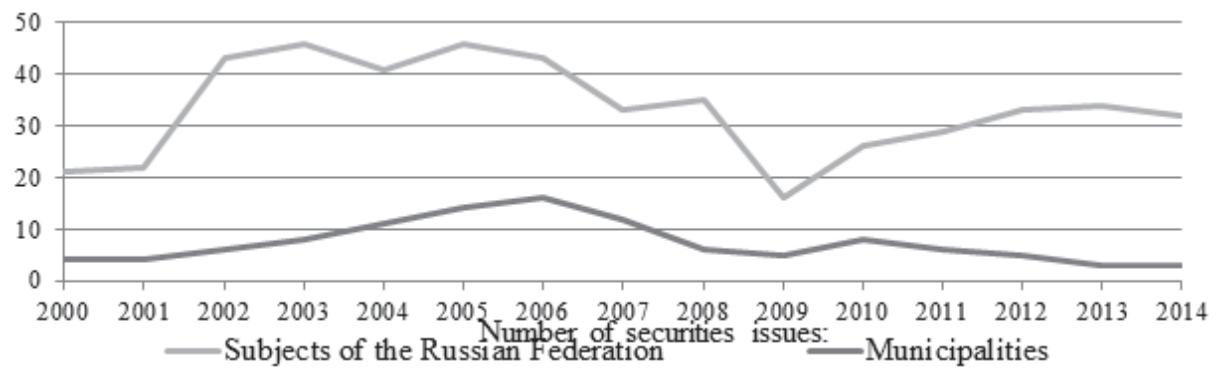

Fig. 1. Dynamics of issue of the state bonds of territorial subjects of the Russian Federation and municipal bonds in Russia in 2000-2014.

Apparently on figure 1, the greatest issue activity of regions was observed in 2005 (48 releases), and municipalities - in 2006 (16 issues), the smallest number of issues of securities of territorial subjects of the Russian Federation was registered in 2009 (16), municipal bonds - in 2013 (3). It should be noted that during 2000 - 2014 issue of the state securities of territorial subjects of the Russian Federation carried out in 53 regions. Dynamics of participation of territorial subjects of the Russian Federation an issue of the state securities are presented in figure 2.

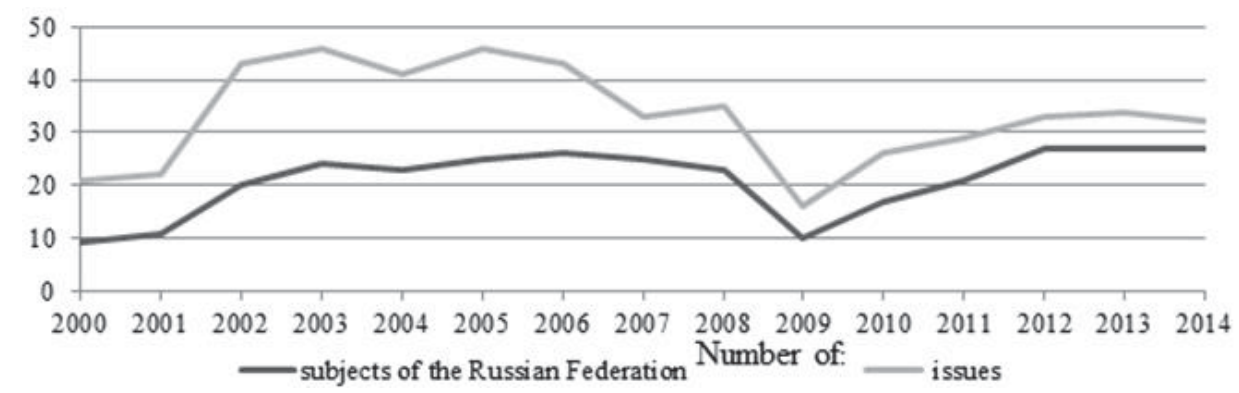

Fig. 2. Number of issues of the state bonds of territorial subjects of the Russian Federation in 2000-2014.

Figure 2 illustrates high issue activity of regions during 2002-2006, and the number of issues grows higher rates, then number of issuers. Since 2009, the schedule of dynamics of issues of bonds has begun to come nearer to the number of regions issuers, i.e. the majority of territorial subjects of the Russian Federation carries out no more than one bonded loan in a year. At the same time the total of subjects issuers steadily increases. The leader by number of issues of 
securities is St. Petersburg: for 2000-2014 81 issues of bonds were registered. The Tomsk region carried out 54 issues of bonds, in Moscow 38 issues are carried out. At other subjects issuers the number of the registered issues of bonds didn't exceed 30, and at 40 of them - no more than 10. If to address to the analysis of participation of certain territorial subjects of the Russian Federation in attraction of resources by the placement of the state bonds, it is possible to allocate 4 groups: the first included the issuers who are annually registering issues (for 15 years - the Volgograd region; 14 years St. Petersburg, Karelia, Chuvashia, the Tomsk region); in the second group - that bonds for 10-14 years (Krasnoyarsk Krai, the Republics of Sakha (Yakutia) and Komi, Moscow, the Tverskaya, Nizhny Novgorod and Yaroslavl areas) let out; in the third - emitting bonds within 6-10 years of the analyzed period (Irkutsk, Samara, Belgorod, Lipetsk, Voronezh, Kostroma, Moscow, Novosibirsk areas; Bashkortostan, Udmurtia, Mari El); other territorial subjects of the Russian Federation issuing the state bonds no more than 5 years, made the fourth group.

When carrying out the analysis of issue activity of municipalities it was revealed that in 2000-2014 bonded loans let out only in 33 of them. Thus the most active were: Volgograd (17 issues within 12 years), Novosibirsk (14 issues of securities in 9 years), Tomsk (9 bonded loans in 8 years), Yekaterinburg and Krasnoyarsk (on 8 issues in 8 years), and also Kazan (6 issues within 6 years) (fig. 3).

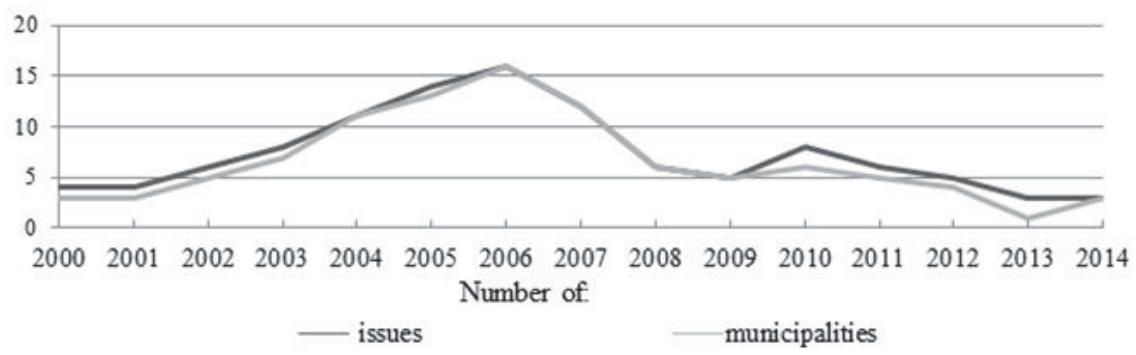

Fig. 3. Number of issues of municipal bonds in 2000-2014.

The analysis of structure of issues of the state bonds of territorial subjects of the Russian Federation on circulation periods is submitted in figure 4 . In the analyzed period more than a half of bonds were issued for up to 5 years (266 registered issues since 500). The considerable part is made by issuers of bonds for a period of up to 30 years.

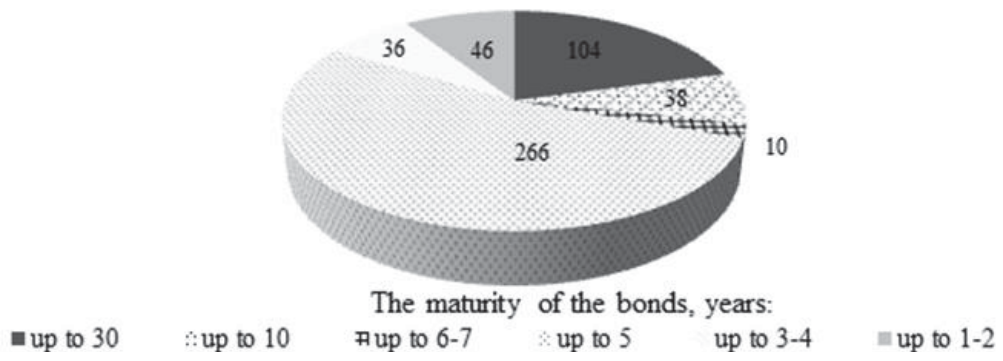

Fig. 4. Structure of issues of the state bonds of territorial subjects of the Russian Federation on circulation periods in 2000-2014.

The results of the analysis of the directions of use of the funds raised by the issue of the state securities of territorial subjects of the Russian Federation are presented in table 1.

Table 1. The directions of use of means from issue of bonds of territorial subjects of the Russian Federation

\begin{tabular}{lc}
\hline Use directions & $\begin{array}{c}\text { Number of issues bonds of subjects } \\
\text { of the Russian Federation }\end{array}$ \\
\hline Financing the budget deficit & 447 \\
\hline Restructuring of debts (2000 and 2002) & 15 \\
\hline Repayment of debts & 408 \\
\hline Calculations are executed on the basis of data of the Ministry of Finance of the Russian Federation [11].
\end{tabular}


According to table 1, the main direction of use of borrowed funds is the financing of a budget deficit of the territorial subject of the Russian Federation, and the smallest - restructuring of debt which was applied only in 2000 and 2002.

According to data on registration of conditions of issues of the state securities of territorial subjects of the Russian Federation from variation of the face values of bonds (ranging from 100 rub to 100000 rub) since 2009 issuers passed to the uniform face value of the bond of 1000 rub. In the last years and an order of definition of the income on bonds I became uniform (the constant (fixed) coupon and a price difference, an exception make separate issues of discount bonds of St. Petersburg) [11]. The average profitability at placement of subfederal bonds in $2013-8,25 \%$ per annum, thus the maximum rate of profitability reached $9,61 \%$ per annum on bonds of the Ryazan region, a minimum level of profitability in 7,1\% per annum on bonds of Moscow [11].

\section{Conclusions}

On the basis of detailed studying of practice of issue of subfederal and municipal securities in Russia in 2000-2014 it is possible to allocate the following:

1. The process of formation of a system of crediting of municipalities by means of implementation of bonded loans is in Russia at an early stage of the development. So, for the considered period of 2000-2014 bonded loans let out only in 33 municipalities.

2. The purpose of the issue of regional bonds isn't development of territories, the use of borrowed funds has no investment character. The main declared direction of the use of means from issue of regional bonds is the financing of a budget deficit of the territorial subject of the Russian Federation, except this means from the issue of bonds of territorial subjects of the Russian Federation went for repayment of debts and debt restructuring.

On the basis of the conducted research the following conclusions were drawn:

1. It is necessary to reconsider the directions of use of means from issues of bonds of territorial subjects of the Russian Federation. In our opinion, today placement of such forms of subfederal loans which allow to carry out development of certain branches of economy of the region, for the purpose of increase the taxable base of the territorial subject of the Russian Federation, creation of new workplaces, decrease in social tension is actual.

2. In medium-term prospect for financing of deficiency of regional budgets primary use of the budgetary credits which will promote replacement of the expensive commercial (bank) credits is supposed that, eventually, has to reduce the risk of the budgetary instability. It should be noted that from the middle of 2014 the rate on the budgetary credits from the federal budget for a covering of deficiencies of the budgets of territorial subjects of the Russian Federation is established on 0,1\% per annum. However, thus, according to authors, regional and local authorities have to and develop further the issue activity, form the public credit history as constantly to count authorities of regions and municipalities on the cheap budgetary credits can't, and in the long-term period bonded loans have become the most demanded instruments of debt financing of the budgetary expenses.

\section{References}

Aguiar, M., Amador, M. Sovereign Debt // Handbook of International Economics, Volume 4, 2015. pp. 647-687.

Dankov, A. N. Problems of development of municipal securities in Russia. Moscow: CEMI RAS, 1998. 19 p.

Dobson E. Debt and investments for the subjects of the Russian Federation. Moscow: Institute for the economy in transition, 2000.205 p.

Fabozzi F.J. Bonds markets, analysis and strategies: 7th edition. Prentice Hall. Upper Saddle River, New Jersey, 2009. 792 p.

Feng, X. Local government debt and municipal bonds in China: Problems and a framework of Rules // Copenhagen Journal of Asian Studies Volume 31, Issue 2, 2013. pp. 23-53.

Joffe, M.D. Rating government bonds: Can we raise our grade? // Econ Journal Watch 9 (3), 2012. pp. 350-365.

Lai, B.C. , Zhang, X. On the Value of Municipal Bond Insurance: An Empirical Analysis // Financial Markets, Institutions and Instruments Volume 22, Issue 4, November 2013. pp. 209-228.

Nguyen, T. Investing in the High Yield Municipal Market: How to Profit from the Current Municipal Credit Crisis and Earn Attractive TaxExempt Interest Income. 2012. 275 p.

Official site of Ministry of Finance of the Russian Federation. The amount of public debt of the Russian Federation and the debt of municipalities // http://minfin.ru/ru/public_debt/subdbt/index.php?\&from_4=2

Official site of Ministry of Finance of the Russian Federation. Report on the results and main directions of activities of the Ministry of Finance of the Russian Federation for 2014 and the planned period 2015-2017 years // http://minfin.ru

Official site of Ministry of Finance of the Russian Federation. Check the terms of issue and circulation of state securities of the Russian 
Federation subjects and municipal securities // http://minfin.ru/ru/public_debt/capital_issue/state_securities/register/

The portal of State programs of the Russian Federation. The Federal program of the Russian Federation «Public Finance Management and regulation of financial markets» // http://programs.gov.ru/Portal/programs/subActionsList?gpld=F6605946-6210-439E-BF9A2A0C42D166B4\&pgpld=1ADC5A36-73B9-456D-ACA5-776035B93370

Rutkauskas, A.V. , Stasytyte, V. , Maknickiene, N. Government debt as the integral portfolio of assets and liabilities generated by debt /I Journal of Business Economics and Management Volume 15, Issue 1, January 2014. pp. 22-40.

Schultz, P. The market for new issues of municipal bonds: The roles of transparency and limited access to retail investors // Journal of Financial Economics Volume 106, Issue 3, December 2012. pp. 492-512.

Bulatov A.N., Mukhametshina G.R., Gazizullina A.R., Toropova N.V. Impact of the project "Enterprise factory" on the regional economy of the Republic of Tatarstan. Mediterranean Journal of Social Sciences.- Vol.5, No18, (2014)-pp. 119-123.

Tserng, H.P., Ho, S.-P., Chou, J.-S., Lin, C. Proactive measures of governmental debt guarantees to facilitate Public-Private Partnerships project // Journal of Civil Engineering and Management Volume 20, Issue 4, 4 July 2014. pp. 548-560. 